\title{
Giant meningioma in paranasal sinuses: an atypical nasal occupation
}

\author{
Diana Pinto Silva, ${ }^{1}$ Sofia Daniela Carvalho, ${ }^{2}$ Nuno Marçal, ${ }^{1}$ Luis Dias ${ }^{1}$
}

'ENT, Head and Neck Surgery, Hospital de Braga, Braga, Portugal

2Department of Pathology, Hospital de Braga, Braga, Portugal

\section{Correspondence to} Dr Diana Pinto Silva, dianapintosilva@gmail.com, dianapintosilva@gmail.com

Accepted 20 December 2017

\begin{tabular}{|l|}
\hline To cite: Silva DP, \\
Carvalho SD, Marçal N, et al. \\
BMJ Case Rep Published \\
Online First: [please \\
include Day Month Year]. \\
doi:10.1136/bcr-2017- \\
223470 \\
\hline
\end{tabular}

\section{DESCRIPTION}

An 80-year-old man presented with a 1-month history of frontal headache and pressure, irradiating to the nose. He did not have other complaints or relevant health issues besides high blood pressure and diabetes mellitus. The initial physical examination did not reveal any abnormality. Because of his severe complaints, he underwent a CT scan of the brain and paranasal sinuses, which showed an expansive solid mass in the right frontal sinus with erosion of its posterior wall and extension to the frontoethmoidal recess. These findings motivated a cranial MRI that revealed a giant mass $(6.3 \times 3.1 \times 7.5 \mathrm{~cm})$ in the frontoethmoidal area with both intracranial and extra-axial extension (figure 1). The patient underwent a frontal sinus biopsy, performed by functional endoscopic sinus surgery that revealed a transitional meningioma with usual epithelial membrane antigen expression (figure 2). A combined approach with neurosurgery team was decided and the patient was submitted to a craniofacial resection with removal of the mass, followed by skull base and ethmoidal roof reconstruction with titanium plates, dura mater and pericranial flap (figure 3). Histopathological analysis was compatible with a WHO grade I meningioma. The patient was discharged on the 12th day, without neurological deficits. He presented a good evolution, without signals of relapse in the follow-up appointments (figure 4).

Meningioma is the most common non-glial intracranial neoplasm. ${ }^{1}$ Its primary or secondary extracranial location is very uncommon. ${ }^{12} \mathrm{~A}$ few cases of extracranial meningioma with sinonasal extension have been reported. ${ }^{2} 3$ Since this is very rare in this location, it imposes a diagnostic challenge. The nasal cavity and paranasal sinuses are extremely close to very important anatomical landmarks. In cases of extensive unilateral sinonasal occupation with extranasal extension is essential to make a careful differential diagnosis. This should include sinonasal malignant masses (squamous cell carcinoma, adenoid cystic carcinoma,

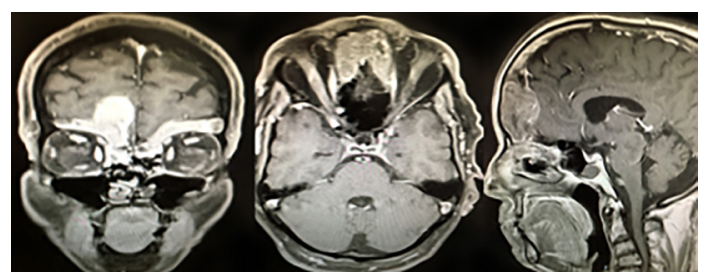

Figure 1 Coronal, transverse and sagittal brain MRI showing giant mass in the frontoethmoidal area with intracranial and extra-axial extension.

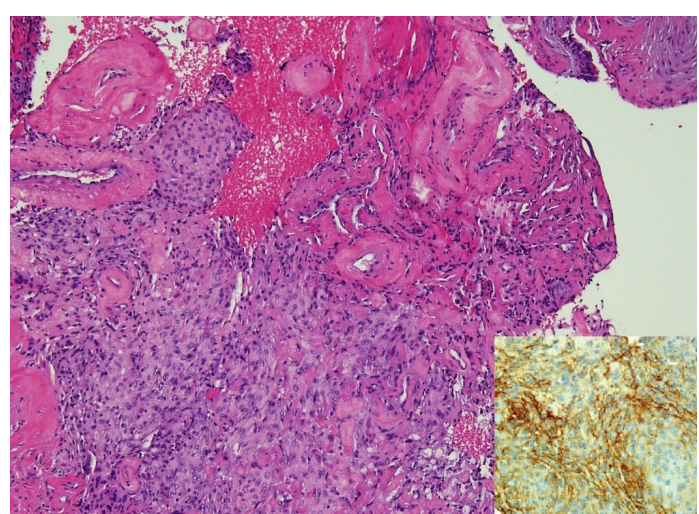

Figure 2 Histologically typical grade I transitional meningioma (H\&E stain, 100x) with usual epithelial membrane antigen expression (inset picture, 400x).

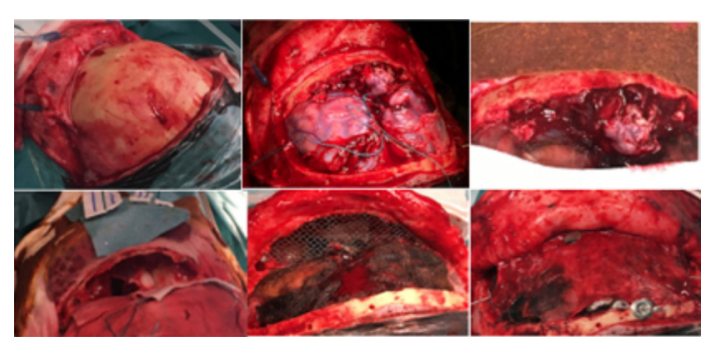

Figure 3 Surgical approach by craniofacial resection with removal of the mass, followed by skull base and ethmoidal roof reconstruction.

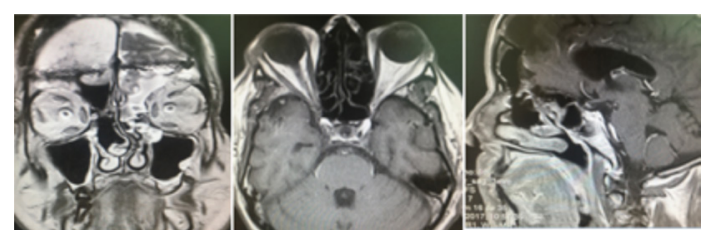

Figure 4 One-year follow-up brain MRI with no signs of relapse.

adenocarcinoma, olfactory neuroblastoma) and benign masses (inverted papilloma, juvenile angiofibroma, osteoma, glioma), complications of sinusitis (mucocele, normally found in the frontoethmoidal area, and mucormycosis, an invasive fungal infection that mostly affects individuals with diabetes), autoimmune diseases (Wegener's granulomatosis), and also extensions from adjacent areas, outside the sinonasal tract, such as meningiomas, meningoencephalocele and orbital tumours. ${ }^{13}$

Histopathology makes a definitive diagnosis. Treatment with complete surgical extirpation has an overall good prognosis. ${ }^{3}$ 
This is an example of a case that shows early diagnosis, treatment and multidisciplinary approaches are pearls for successful outcomes.

\section{Learning points}

- Patients' complaints are key to establishing an early diagnosis.

- Uncommon locations of common diseases represent a diagnostic challenge and may delay the correct diagnosis.

- Multidisciplinary approaches positively affect the prognosis.
Contributors Collaboration, teaching and guidance: DPS, SDC, NM, LD.

Competing interests None declared.

Patient consent Obtained.

Provenance and peer review Not commissioned; externally peer reviewed.

(C) BMJ Publishing Group Ltd (unless otherwise stated in the text of the article) 2018. All rights reserved. No commercial use is permitted unless otherwise expressly granted.

\section{REFERENCES}

1 laconetta G, Santella A, Friscia M, et al. Extracranial primary and secondary meningiomas. Int I Oral Maxillofac Surg 2012;41:211-7.

2 Wadhera R, Hernot $\mathrm{S}$, Kaintura M, et al. Primary extracranial meningioma as a very rare cause of nasal mass and epistaxis in an elderly. J Clin Diagn Res 2016;10:MD01-3.

3 Rushing EJ, Bouffard JP, McCall S, et al. Primary extracranial meningiomas: an analysis of 146 cases. Head Neck Pathol 2009;3:116-30.

Copyright 2017 BMJ Publishing Group. All rights reserved. For permission to reuse any of this content visit http://group.bmj.com/group/rights-licensing/permissions.

BMJ Case Report Fellows may re-use this article for personal use and teaching without any further permission.

Become a Fellow of BMJ Case Reports today and you can:

- Submit as many cases as you like

Enjoy fast sympathetic peer review and rapid publication of accepted articles

- Access all the published articles

Re-use any of the published material for personal use and teaching without further permission

For information on Institutional Fellowships contact consortiasales@bmjgroup.com

Visit casereports.bmj.com for more articles like this and to become a Fellow 